V. Kovalev, G. Klymenko, Y. Vasylchenko, M. Shapovalov, O. Antsiferova, I. Maiskykh, Kramatorsk, Ukraine

\title{
RESULTS OF INDUSTRIAL TESTING OF CARBIDE CUTTING TOOLS BY PULSED MAGNETIC FIELD TREATMENT AND THE EFFECT ON THE INCREASE OF THE CUTTING PROCESS EFFICIENCY
}

\begin{abstract}
The task of increasing the efficiency of machining parts on heavy machines was determined, scientifically substantiated and solved by hardening a carbide tool the pulsed magnetic field processing $(P M F P)$. The efficiency of machining of parts is understood as an increase in its productivity, a reduction in the cost and costs of tool materials, and an increase in instrument reliability. The working conditions of cutting tools at heavy engineering enterprises are analyzed. The wear resistance of carbide cutting tools, which have been strengthened by the PMFP, was investigated using forced test methods and modeling of the cutting process. The mechanism of changing the properties of a hard alloy under the action of a pulsed magnetic field is established. The main factors affecting the change in the wear resistance of a hard alloy under the action of a pulsed magnetic field are identified. The effect of pulsed magnetic field processing on the performance of carbide cutting tools under production conditions is investigated. The effect of hardening on productivity, cost of operation and instrumental costs is established. The interrelation of the parameters of the PMFP, the parameters of the process of machining parts and production efficiency is investigated. A statistical model has been developed that allows determining the productivity of mechanical processing depending on the properties of the tool material and the processing parameters of a pulsed magnetic field.
\end{abstract}

Keywords: pulsed magnetic field processing; carbide tools; heavy machine production tests; sustainability; magnetic field strength; pulse frequency; performance.

\section{Introduction}

An important task is to improve the tooling of new machines for highprecision productive machining of difficult-to-machine materials by applying the latest tool strengthening methods. An analysis of different methods for enhancing the physical and mechanical properties of hard-alloy tool materials showed that the best combination of cost and production efficiency was observed with the pulsed magnetic field machining method. In this study, metal machining efficiency was evaluated in terms of objective functions which characterise productivity Q, cost C and tooling cost $\mathrm{S}$ depending on tool resistance and cutting modes. In these functions, the influence of tool resistance dissipation was also taken into account. It is established that in hard conditions of cutting it is reasonable to optimize a cutting mode taking into account the dissipation of the tool resistance. As in production conditions the tool resistance dissipation takes place, the cutting conditions should be prescribed in order to ensure the durability with a given reliability P.

(C) V. Kovalov, G. Klymenko, Y. Vasylchenko, M. Shapovalov, O. Antsiferova, I. Maiskykh, 2021 
This resistance is called gamma percent resistance and is determined with the help of tool failsafe operation graphs, compiled by the results of observations of tool operation. The use of machining by pulse magnetic field of hard-alloy tools increases the value of optimal feed by a factor of 1.2-1.3.

As the industry develops, the demands on machine tools, increasing precision and quality of their manufacture, and the introduction of new, stronger materials that enable higher levels of performance are increasing. An important task is to improve the tooling of new machines for high-precision productive machining of difficult-to-machine materials through the use of the latest tool strengthening methods. One of the perspective technologies for increasing strength, service life and operational properties of metal products for various fields of technology is machining with a pulsed electromagnetic field.

This is particularly relevant for hard-alloy cutting tools. It is well known that hard alloys have, on the one hand, a high heat resistance, which allows cutting tools to operate at high cutting speeds. On the other hand, hard alloys have a low bending strength, which limits their ability to work in previous, roughening operations, where the tool is subjected to shock loads, which are generated by workpieces made by casting or forging methods, abrasive dust, unevenness of assumptions, etc.

Analysis of different methods of improving the physical and mechanical properties of hard-alloy tool materials has shown that the best combination of cost and production efficiency is observed in the method of machining by pulsed magnetic field (MPMF). The essence of MPMF is that the metal-cutting tool before machining is placed in a cavity of a magnet connected to a pulse generator. Under magnetic influence the metal changes its physical and mechanical properties. The magnetic pulse field interacts with the metal-cutting tool material, changing its thermal and electromagnetic properties and improving its structure and performance. Improved properties in metal-cutting tools are achieved by directing the free electrons of the material by an external field, resulting in an increase in the thermal and electrical conductivity of the material. The main advantages of MPMF are: strengthening of metal-cutting tools of any design, simplicity of technological tooling and absence of consumables, environmental friendliness, low cost [1-5].

To implement the MPMF process, a control unit is used to set the workpiece machining modes, i.e. to set certain parameters of the magnetic energy and the duration of its effect.

The process which is connected with metals machining with cutting, by definition of Prof. M. Klushin, is a system of cutting, which consists of elements, which in our case are separate processes. The state of the system is characterized by a selection of values of a number of variables (factors, indicators), and the behavior of the system - a sequence of states in time. 


\section{Experimental procedure}

The system has the property of relative resistance in the sense that it is maintained only within certain limits of variation of its variables. For our case previous machining of metals with hard-alloy cutting tools that are reinforced with MPMF, the system is represented in Figure. 1 as a relationship of parameters that characterise the machining process and production efficiency from MPMF.

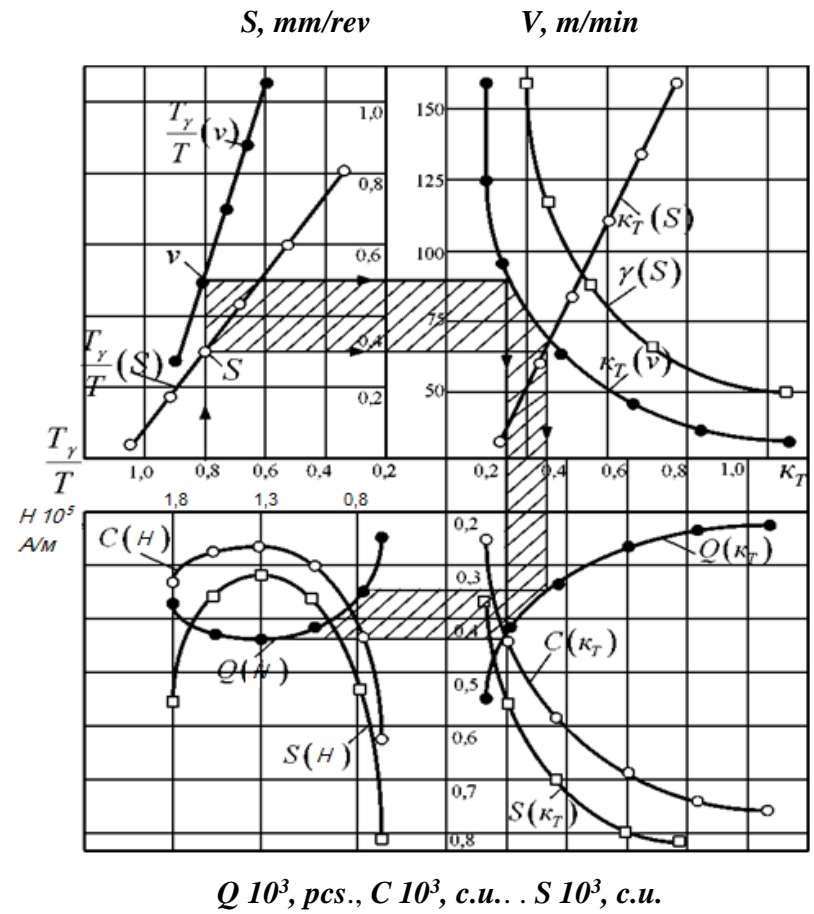

Figure 1 - Relationship between machining parameters and production process efficiency during the use of MPMF

Figure 1 provides recommendations from determining the coefficient of variation of tool resistance KT, Weibull distribution parameter $\gamma$, gamma percent tool resistance $\mathrm{T}_{\gamma}$ depending on given cutting modes $v$ and $\mathrm{S}$, as well as reasonable values of company efficiency indicators: productivity $\mathrm{Q}$, cost price $\mathrm{C}$ and tool costs $\mathrm{S}$. The sequence of connections is defined by arrows.

Due to its autonomy, the mentioned system may be considered as a subsystem or an element of a wider system. The study of the system is carried out 
by changing external influences on it "at the input" and studying its response "at the output", which are commonly referred to as functions of the system or parameters of its functioning.

The system state variables in the mentioned case are:

1. The material that is machined, its properties: hardness, strength boundary;

2. The machining operation - removed assumption, reference surface condition, cutting conditions;

3. Cutting tool - tool material (composition, properties), geometric and structural parameters;

4. The stiffness of the system, its dynamic properties;

5. Parameters of the MPMF - strength of magnetic field, frequency of pulses.

The results of system functioning were considered as follows:

1. Resistance of the cutting tool, gamma percent resistance;

2. The variation of resistance;

3. Machining performance;

4. Cost of operation;

5. Tooling costs.

Each of the parameters of system functioning is more or less influenced by all the variables of its state, as well as their mutual influence. In general, the system under consideration is characterized by a large number of possible states and numerous links between its elements, i.e. it is a complex system.

Since at this time the real physical content of the mechanisms through which the interaction of the system's state variables on each of its indicators is carried out remains revealed only in the main features, the relationship between the parameters will be defined in the form of statistical models, which characterize the relationship between the main variable factors of the system and the parameters that characterize the efficiency of production.

Let us present the factors that influence the functioning parameters for such groups:

1 group. Factors that characterize the design and geometric parameters of the tools:

- front angle $\gamma$

- posterior angle $\alpha$;

- The main angle in the plane $\varphi$;

2 group. Factors that characterise the quality of tool construction:

- Rear surface roughness $\mathrm{R}_{\mathrm{zzn}}$;

- roughness of the front surface $\mathrm{R}_{\mathrm{zzn}}$;

- Hard alloy hardness boundary $\sigma_{\mathrm{B}}$;

3 group. Factors that characterise workpiece quality are: 
- unevenness of assumption in the workpiece $h_{3}$;

- hardness of the machined material HB;

- strength limit of the machined material $\sigma_{\mathrm{B}}$;

- yield strength of the machined material $\sigma_{T}$;

4 group. Factors which characterize the MPMFP process:

- magnetic field strength $\mathrm{H}$;

- pulse frequency f;

5 group. Factors which characterise properties of the tool material:

- HRC hardness;

- durability;

- Red resistance.

The factors given in groups 3 and 5 were not considered because no information could be obtained at the time of screening regarding factors in the production environment that would allow to establish a correlation with tool resistance.

Theoretically, any space can be considered. In practice, this involves more or less time spent on the state of the programme and analysis of the results.

In a first step, a correlation analysis was carried out to screen out the factors beforehand. Behind the dimensions of the correlation characteristics, the density of the correlation between the resistance and the factors can be established and those factors that have the strongest correlation with the tool resistance within its dispersion range can be singled out.

Since there can be both a linear and a non-linear connection between the factors considered and resistance, a correlation relation was used to assess the closeness of this relationship, which was determined using the formula:

$$
\eta=\sqrt{\frac{\sigma^{2}-\sigma_{y}^{2}}{\sigma^{2}}}
$$

where $\quad \sigma^{2}=\frac{1}{n} \sum(y-\bar{y})^{2}, \quad \sigma_{y}^{2}=\frac{1}{n} \sum\left(\bar{y}_{j}-\bar{y}\right)^{2} ;$

$\overline{y_{j}}$ - group average.

The data for the correlation analysis were obtained under production conditions by testing. Table 1 shows the values of the correlation relations between the resistance and the technological factors, which are calculated according to formula 1 .

As can be seen from Table 1, the correlation relationships between resistance and such factors as front angle, main angle in plan, percentage of tungsten carbide has a value from 0.09 to 0.18 . This demonstrates that the marked factors have insufficient closeness to the resistance within its dispersion range and, therefore, will not be taken into account further. 
Table 1 - Correlation relationships between tool resistance and technology factors

\begin{tabular}{|l|c|}
\hline \multicolumn{1}{|c|}{ Factors that affect resistance } & Correlation ratio \\
\hline 1. Front angle $\gamma$ & 0,18 \\
\hline 2. Main angle in plan $\varphi$ & 0,16 \\
\hline 3. Percentage of tungsten carbide $W C$ & 0,09 \\
\hline 4. Magnetic field strength $H$ & 0,48 \\
\hline 5. Pulse frequency $f$ & 0,35 \\
\hline 6. Percentage of cobalt $C_{o}$ & 0,42 \\
\hline 7. Hard alloy strength limit $\sigma_{\mathrm{B}}$ & 0,34 \\
\hline
\end{tabular}

The above results of the analysis, although it made it possible to narrow the description space to 7 factors, but did not allow us to identify the dominant factors, so the next stage was to calculate the correlation coefficient between the factors using the expression:

$$
r_{i j}=\frac{\sum_{k=1}^{n}\left(x_{i k}-\overline{x_{k}}\right)\left(x_{j k}-\overline{x_{j k}}\right)}{\sqrt{\sum_{k=1}^{n}\left(x_{i k}+\overline{x_{i k}}\right)^{2}} \sum_{k=1}^{n}\left(x_{j k}-\overline{x_{j k}}\right)^{2}},
$$

where $i, j$ - the numbers of the factors between which the inter-correlation coefficient is calculated;

$x_{i k}, x_{j k}$ - pair of factors in question;

$\overline{x_{l k}}, \overline{x_{j k}}$-average values of the factors.

$$
\overline{x_{l k}}=\frac{1}{n} \sum_{k=1}^{n} x_{i k}, \quad \overline{x_{j k}}=\frac{1}{n} \sum_{k=1}^{n} x_{j k} .
$$

The significance of correlation coefficients was assessed using Student's criterion :

$$
|r|=\frac{t_{\mathrm{kp}}}{\sqrt{t_{\mathrm{kp}}^{2}+n-2}} .
$$

It should be noted that if the calculated value of the correlation coefficient $r$ turns out to be greater than the assumed value (14), then the mutual influence of the pair of factors xi and $x j$ cannot be neglected.

The statistic which characterises the contribution of any factor to the total variance was the assumed variance of the normalised value of that factor. The factors were normalised by this transformation:

$$
x_{i k}=\frac{x_{i k}-\frac{x_{i \max }+x_{i \min }}{2}}{\frac{x_{i \max } x_{i \min }}{2}},
$$


where xi is the current value of the factor in physical terms;

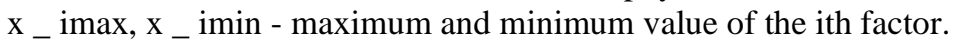

The marked transformation allows all properties to be reduced to a single scale and provides the opportunity to compare them from each other. The variance of the normalised values was determined by the formula:

$$
\sigma\left\{x_{i}\right\}=\frac{\sum_{k=1}^{n}\left(x_{i k}-\overline{x_{i k}}\right)^{2}}{n-1}
$$

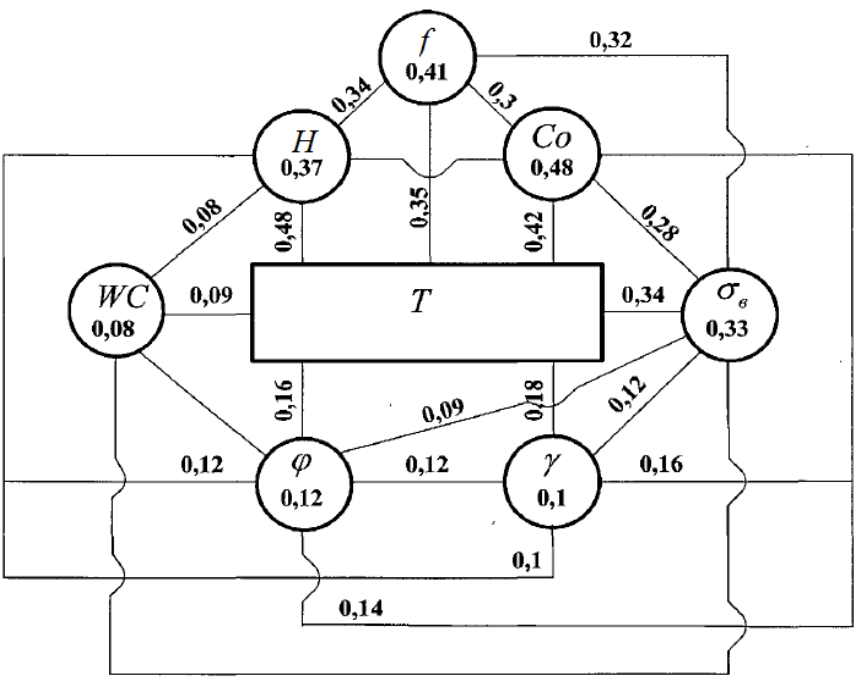

Figure 2 - Diagram of the relationship between factors and the relationship of factors to resistance

Figure 2 shows a diagram of the relationship between the factors and the relationship between the factors and resistance. The sizes of the variances of the normalised values in circles are shown for the main attributes. The lines that connect the attributes correspond to the highlighted relationship. The size of the latter can be judged by means of correlation coefficients, which are shown in the marked scheme.

Thus, the preliminary studies suggest that the dominant factors are the magnetic field strength $H$, the hard alloy strength boundary $\sigma \mathrm{v}$, the cobalt content in the $C_{o}$ hard alloy, and the pulse frequency $\mathrm{f}$. 
As a model to describe the dependence of machining performance, which was defined by formula, on the variation of magnetic field strength $x_{1}(H)$, pulse frequency $x_{2}(f)$, cobalt content in the hard alloy $x_{3}\left(C_{o}\right)$, hard alloy strength limit $x_{4}$ $\left(\sigma_{6}\right)$, the first degree equation with interactions was applied:

$$
\begin{gathered}
y=b_{0}+b_{1} x_{1}+b_{2} x_{2}+b_{3} x_{3}+b_{4} x_{4}+b_{12} x_{1} x_{2}+b_{13} x_{1} x_{3}+b_{14} x_{1} x_{4}+b_{23} x_{2} x_{3}+ \\
+b_{24} x_{2} x_{4}+b_{34} x_{3} x_{4}++\quad+b_{123} x_{1} x_{2} x_{3}+b_{234} x_{2} x_{3} x_{4}+b_{134} x_{1} x_{3} x_{4}+ \\
+b_{124}+x_{1} x_{2} x_{4}+b_{1234} x_{1} x_{2} x_{3} x_{4}
\end{gathered}
$$

The above equation can be obtained by varying each of the factors $x_{i}$ at the upper $x_{i v}$ and lower xin levels, which differ from the base level xio by the size of the variation step $\pm \Delta \mathrm{x}_{i}$.

A complete factor experiment of the form $2^{4}$ has been adopted as the basis of the experimental plan, where 2 is the number of levels (upper and lower) of independent variables; 4 is the number of independent fungible variables.

This plan allows for all possible unrepeated combinations of levels of independent variables, each of which is forced to vary at two levels.

To simplify the calculations, the independent variables were coded by the transformation formula :

$$
z_{i}=\frac{x_{i}-x_{i 0}}{\Delta x_{i}}
$$

The size of the lower and upper level and, respectively, the size of the variation step for each variable had the following values:

$-H: x_{1 H}=0,8 \cdot 10^{5} \mathrm{~A} / \mathrm{M}, x_{16}=1,3 \cdot 10^{5} \mathrm{~A} / \mathrm{M}, \Delta x_{l}=0,25$;

$-f: x_{2 H}=5 \mathrm{~Hz}, x_{28}=10 \mathrm{~Hz}, \Delta x_{2}=2,5$;

$-C_{o}: x_{3 H}=6 \%, x_{36}=10 \% ; \Delta x_{3}=2$;

$-\sigma_{6}: x_{4 H}=5,1 \cdot 10^{8} \mathrm{~Pa}, x_{46}=6,3 \cdot 10^{8} \mathrm{~Pa}, \Delta x_{4}=0,6$.

Each row shows the levels of values of the variables that have been assigned to a particular point in the factor space.

The coefficients of the interproximal function were determined by the formula:

$$
b_{i}=\frac{\sum_{m=1}^{N} x_{i m} y_{m}}{N} .
$$

Mathematical model of dependence of machining capacity on parameters of change of magnetic field strength $x_{I}(H)$, pulse frequency $x_{2}(f)$, cobalt content in hard alloy $x_{3}\left(C_{o}\right)$, hard alloy strength limit $x_{4}(\sigma 4)$ according to results of conducted test can be written in the form:

$$
\begin{aligned}
& y=2,795+0,828 z_{1}+0,025 z_{2}+0,358 z_{3}+{ }^{\prime} 0,369 z_{4}-0,006 z_{5}+ \\
& +0,115 z_{6}+0,126 z_{7}+0,016 z_{8}+0,027 z_{9}-0,148 z_{10}-0,117 z_{11}+
\end{aligned}
$$




$$
+0,145 z_{12}-0,102 z_{13}-0,019 z_{14}-0,049 z_{15}
$$

\section{Conclusions}

1. It has been established that the use of pulse magnetic field machining improves the optimum resistance by a factor of 1.4-2.

2. For tools, which work in conditions of heavy cutting, use of pulse magnetic field machining promotes increase of optimum feed by a factor of 1,151,3 times.

3. Using the factor analysis of 24 , type, the dependence of machining productivity of cutters, which are reinforced with MPMF, from intensity of magnetic field $\mathrm{H}$, hard alloy strength limit $\sigma \mathrm{v}$, cobalt content in hard alloy $\mathrm{Co}$, pulse frequency $f$ was determined

References: 1. Quan S. Effect of pulsed magnetic field treatment on the residual stress of 20Cr2Ni4A steel / Quan S., Jiajie K., Zhiguo X., Haidou W., Yanfei H., Guozheng M., Haipeng L. // Journal of Magnetism and Magnetic Materials. - 15, April 2019. Volume 476. - pp. 218-224. https://doi.org/10.1016/j.jmmm.2018.12.105. 2. Huang Xinquan C. Residual stress reduction by combined treatment of pulsed magnetic field and pulsed current / Huang Xinquan C. // Materials Science and Engineering:A., 25 July 2011. - Volume 528. - Issues 19-20/ - pp. 6287-6292. https://doi.org/10.1016/j.msea.2011.04.078. 3. Ma L. An investigation on the mechanical property changing mechanism of high speed steel by pulsed magnetic treatment / Ma L., Zhao W., Liang Z., Wang X., Xie L., Jiao L., Zhou T. // Materials Science and Engineering: A., 15 July 2014, - Volume 609. - pp. 16-25. https://doi.org/10.1016/j.msea.2014.04.100. 4. Shapovalov M. Kovalov V., Vasylchenko $Y$. Increase the productivity of hard-alloy tools for heavy machine tools by processing impulse magnetic field Вісник ТНТУ. Тернопіль, 2018. № 3 (50). С. 52-59. 5. Kovalov V., Vasilchenko Y., Shapovalov M, Turmanidze R., Dašić P. Impact of a Pulsed Magnetic Field on a Hard Alloy During Machining on Heavy Machine Tools. International Journal of Industrial Engineering and Management (IJIEM), Vol. 10 No 1, 2019, Pp. 125-130. ISSN 2217-2661. https://doi.org/10.24867/IJIEM-2019-1-125. 6. Rodichev Y., Soroka O., Kovalov V., Vasilchenko Y., Maiboroda V. (2020) Fracture Resistance of the Edge of Cemented Carbide Cutting Tool. In: Tonkonogyi V. et al. (eds) Advanced Manufacturing Processes. InterPartner 2019. Lecture Notes in Mechanical Engineering. Springer, Cham. https://doi.org/10.1007/978-3-030-40724-7_29.

Віктор Ковальов, Галина Клименко, Яна Васильченко, Максим Шаповалов, Олеся Анциферова, Ігор Майських, Краматорськ, Україна

\section{РЕЗУЛЬТАТИ ПРОМИСЛОВИХ ВИПРОБУВАНЬ ТВЕРДОСПЛАВНОГО РІЗАЛЬНОГО ІНСТРУМЕНТУ ОБРОБЛЕНОГО ІМПУЛЬСНИМ МАГНІТНИМ ПОЛЕМ І ВПЛИВ НА ПІДВИЩЕННЯ ЕФЕКТИВНОСТІ ПРОЦЕСУ РІЗАННЯ}

Анотація. Поставлено, науково обтрунтовано та вирішено завдання підвищення ефективності обробки деталей на важких верстатах шляхом змічнення твердосплавного інструменту обробкою імпульсним магнітним полем (ОІМП). Досліджено зносостійкість твердосплавних 


\section{ISSN 2078-7405 Cutting \& Tools in Technological System, 2021, Edition 95}

різальних інструментів, зміџнених ОІМП, з використанням методів форсованих випробувань та моделювання процесу різання. Встановлено механізм зміни властивостей твердого сплаву під впливом імпульсного магнітного поля. Виявлено основні чинники, ще впливають на зміну зносостійкості твердого сплаву під впливом імпульсного магнітного поля.

Досліджено вплив обробки імпульсним магнітним полем на працездатність твердосплавного різального інструменту у виробничих умовах. Встановлено вплив загартування на продуктивність, вартість експлуатації та інструментальні витрати. Проведено оиінку ефективності обробки металів різанням за иільовими функиіями, що характеризують продуктивність $Q$, собівартість $C$ i інструментальні витрати $S$ в залежності від стійкості інструментів $i$ режимів різання. У ичих функиіях враховувалося також вплив розсіювання стійкості інструментів. Оиінка ефективності обробки металів різанням дозволила встановити підвищення оптимальної стійкості інструментів, зміцнених ОІМП в 1,4-2,5 рази, а також дати практичні рекомендації щцодо визначення оптимальної подачі. Використовуючи результати виробничих випробувань, на основі принципів системного підходу представлено взаємозв'язок параметрів механічної обробки $i$ ефективності виробничого процесу при використанні ОІМП. Розроблено статистичну модель, щчо дозволяє визначити продуктивність механічної обробки залежно від властивостей інструментального матеріалу та параметрів обробки імпульсним магнітним полем. Після оцінки кореляційних відношень за допомогою повного факторного експерименту була визначена залежність продуктивності обробки зміџненими різиями від домінуючих чинників: напруженості магнітного поля, межі міџності твердого сплаву, вмісту кобальту в твердому сплаві, частоти імпульсів, яка має практичне застосування.

Ключові слова: оброблення імпульсним магнітним полем; твердосплавний інструмент; важкий верстат; виробничі випробування; стійкість; напруженість магнітного поля; частота імпульсів; продуктивність. 